\title{
REPENSAR AL AUTOR EN LA LITERATURA CONTEMPORÁNEA
}

\author{
RETHINKING THE AUTHOR IN CONTEMPORARY LITERATURE
}

\author{
Julia E. Negrete Sandoval \\ Investigadora independiente \\ juli7mas@hotmail.com
}

\begin{abstract}
RESUMEN: Entre las muchas perspectivas desde las que se han estudiado la autobiografía y la autoficción, se echa de menos una aproximación teórica que dé cuenta de las dificultades planteadas por uno de sus elementos fundamentales: el autor. Los estudios autoriales recientes destacan la importancia de volver la mirada sobre la instancia autorial a fin de reevaluar los vínculos con su propia obra y el papel que juega en el entramado de las relaciones que esta establece con el contexto. Al dar lugar a autofiguraciones, los géneros autobiográficos problematizan el estatuto del creador $y$, por lo tanto, lo convierten en el centro del conflicto realidad-ficción, origen de numerosas discusiones. Por esta razón, aquí propongo una reflexión que considera al autor como el indicador principal del carácter referencial adjudicado a ambos géneros, pero también, y por su misma naturaleza inestable y fragmentada, como la fuente de las paradojas que contaminan a la autobiografía y definen a la autoficción.
\end{abstract}

PALABRAS ClAVE: Autor, autobiografía, autoficción, referencialidad, ficción

ABSTRACT: Among the various perspectives from which autobiography and autofiction have been studied, there is no theoretical approach that shows the difficulties created by one of the main elements of these genres: the author. Recent studies about the author underline the importance of going back to this concept to reevaluate the connections between writers and their work, along with the role it plays in their relationships with the context. Because they create autofigurations, autobiographical genres problematize the creator's status and, for instance, he/she becomes the center of the conflict between reality and fiction (origin of numerous discussions). For this reason, in this paper I propose an analysis that considers the author as the main focus of the referentiality related to both genres but also - due to its own unstable and fragmented nature- as the source of the paradoxes that taint autobiography and define autofiction. 
KEYWORDS: Author, Autobiography, Autofiction, Referentiality, Fiction

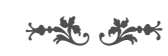

En la historia de la autobiografía, el siglo xx ha sido un periodo de extensa reflexión en torno a los elementos que condicionan su naturaleza genérica y su estatuto referencial. En particular, la segunda mitad del siglo atestiguó un debate enriquecido por la incorporación de perspectivas que insistían en situarla en los límites entre el discurso histórico y el ficcional, porque si bien su construcción se ve afectada por los problemas que plantea la representación, su función pragmática sigue siendo la de dar cuenta de una vida situada históricamente (Loureiro 1991 y Pozuelo Yvancos 1993: 179-226). Durante este mismo periodo, al lado del género autobiográfico, o quizás como consecuencia de las dificultades irresueltas sobre la relación conflictiva entre realidad y ficción, una parte de la teoría literaria se inclinó por el estudio de una modalidad genérica en la que se multiplican las dimensiones de los problemas señalados por este género. La autoficción se impuso como correlato de la autobiografía en un contexto de notable incremento en el interés por el individuo y los pormenores de su existencia. Al parecer, la vida, con toda su "realidad", se ha empeñado en apropiarse de los discursos, en forzarlos no solo a representarla sino a reproducirla: el arte quiere dar cuenta de su creador y experimenta con los recursos que mejor le sirvan para apresar "lo real", precisamente porque se sabe que tal apropiación es imposible. Una cuestión de fondo en este altercado entre dos géneros por definirse como más o menos ficcionales es, sin embargo, el autor, instancia chocante, conflictiva, que en un solo gesto permite y obstaculiza su propia representación. De ahí que sea preciso ubicar el lugar o los lugares donde se generan las tensiones de la identidad de un yo escurridizo, las mismas que han motivado su puesta en escritura para ver si así es posible percibir su unidad, aunque sea solo para confirmar las sospechas de que se persigue a un fantasma. Porque para que el autor sea manejable, en tanto materia de su propio relato, necesita descomponerse, separarse de su corporalidad, "auto-objetivarse" -si usamos el término de Bajtín (1982: 21-23)-, verse como otro, convertirse en otro, que no puede, sin embargo, deshacerse de aquel dotado de un nombre ligado a un cúmulo de experiencias. Por eso, estas páginas se proponen volver la mirada sobre el autor, reflexionar acerca su papel en el juego literario y, sobre todo, de detectar los puntos de inflexión donde la evasión de la referencialidad intrínseca a la instancia autorial incorporada en la dinámica de autobiografías, autoficciones y otras escrituras del yo se revela como el deseo de aprehender la realidad para deshacerla y, con sus retazos, proyectar la figura misma del escritor.

\section{EL AUTOR COMO REFERENTE}

La noción más general de autor que se conserva en la actualidad implica aspectos de causa, origen y propiedad; según se lee en el DRAE: un autor es una per- 
sona que es "causa de algo", "que inventa algo" o "que ha producido alguna obra científica, literaria o artística" (2014, s. v. "autor"). En palabras de Martha Woodmansee, por autor entendemos "an individual who is the sole creator of unique 'works' the originality of which warrants their protection under laws of intellectual property known as 'copyright' or 'authors' rights'" (1994: 15). A este apego a la concepción moderna del autor, heredada del romanticismo, como el genio creador, dotado de originalidad por el hecho mismo de ser un individuo con un talento único que lo separa del resto de los mortales, se opone, sin embargo, un aspecto que resta solidez a la autoría única para otorgársela a una colectividad anónima extraviada en el ciberespacio. Si las actuales leyes del copyright siguen protegiendo la propiedad intelectual en tanto producto de una entidad cuyo nombre es, al mismo tiempo, marca personal y marca comercial de una obra, el carácter colectivo de la autoría mediática, por el contrario, ejerce la negación de la individualidad creativa, echa abajo la originalidad, menosprecia la propiedad privada de los textos y pone en duda el valor del nombre que la avala. Esta vuelta de tuerca hace eco de las no muy lejanas propuestas de deshacerse del autor derivadas del formalismo, los estudios de la intertextulidad, el estructuralismo y el posestructuralismo, por no decir que recuerda el carácter colaborativo de la autoría medieval. ${ }^{1}$ En la era del Internet surge la duda, o mejor, la predicción, sobre la desaparición del autor. No obstante, asistimos también a la urgencia de la expresión de lo personal y lo privado, a un ansia por crear imágenes, más o menos reales, más o menos inventadas para el consumo público. En la literatura, la proliferación de autobiografías y, especialmente, de autoficciones dentro de las escrituras del yo, reclama un nuevo estatuto para el autor. En estos géneros el escritor se coloca a sí mismo en el centro del su relato, hace de su identidad el motivo de una búsqueda y de su experiencia vital, el hilo de la historia, todo para explicar(se) el devenir escritor y su relación particular con la escritura y, crear, al mismo tiempo, una imagen de sí como correlato de sus textos, una imagen que donar a la posteridad. Por ello, aquí interesa destacar este segundo aspecto con el fin de generar preguntas acerca de la construcción textual del autor, es decir, del despliegue de imágenes que el escritor proyecta de sí, especialmente en

\footnotetext{
1 Al hablar de la autoría en la Edad Media es común retomar el comentario de San Buenaventura sobre la factura de libros en el siglo XIII. Él distingue cuatro formas de hacer un libro que corresponde a cuatro instancias que participan en el proceso y que asumen distintas funciones. En primer lugar, está el scriptor o escriba, que no es sino el copista; en segundo, el compilador, quien reúne pasajes de otros textos en un mismo libro; en tercero, el comentador, quien añade sus propias palabras a las de otros; y en cuarto lugar se encuentra el auctor, quien escribe tanto sus propias palabras como las de otros, pero poniendo las suyas en primer lugar y agregando las ajenas para reafirmar las suyas. Si bien este último se acerca al autor de nuestros días, para San Buenaventura ninguno es más importante que el otro, los cuatro se encuentran al mismo nivel. En otro sentido, sin embargo, el autor medieval, el auctor, parece estar altamente especializado y tener una identidad privilegiada, pues su fución se relaciona con la pregunta sobre la autoridad y, especialmente, con la misma autoridad de Dios. El auctor posee autoridad: auctoritas. Ya que recibe esta autoridad de Dios, es acreedor de credibilidad y respeto. No obstante, su nombre carece de importancia, pues la cultura del manuscrito era prácticamente anónima; la distribución de los manuscritos, o libros copiados, se hacía dentro del círculo de conocidos, por lo que imprimir el nombre resultaba innecesario. Autores no eran los contemporáneos, sino los escritores de la antigüedad. La autoridad estaba en la lectura y no en la escritura, y la lectura, por lo demás, era privilegio de unos cuantos (véase Bennett 2005: 38-43).
} 
textos de naturaleza autobiográfica, donde más explícitamente la autofiguración se encamina a la construcción de una figura de autor con la cual posicionarse en la esfera social.

Una de las salidas que la reflexión teórica reciente pone sobre la mesa de discusión es la consideración del autor en tanto sujeto histórico y como concepto, como punto álgido que recoge los argumentos de "lo real", en términos factuales, y lo imaginado, o lo que es lo mismo una exterioridad relativa al mundo compartido con los otros y una interioridad sobre la que reposa la interpretación de ese mundo; en otras palabras, el autor se descubre en su relación con la escritura y con las condicionantes que determinan su estatuto autorial. Después de todo, este concepto es, con mucho, responsable de colocar la autobiografía en tensión con las apuestas autoficcionales de crear "figuras de autor" que terminan por (con)fundirse con el yo autobiográfico. Al hablar de autoficción tropezamos con unos rasgos que se diferencian de la autobiografía en la libre elección de registros discursivos que enriquecen y complican la estructura de la narración tradicional añadiendo un elemento lúdico; además, el uso del nombre que la autobiografía exige como requisito para establecer la identidad entre autor, narrador y personaje, en la autoficción, si bien resulta indispensable, es también susceptible de una cierta flexibilidad que induce a juegos identidad y de enmascaramiento. ${ }^{2}$ Amén de otras diferencias más sutiles, lo que las une es la puesta en escritura de un "yo" arrebatado al autor. De ahí que el nombre adquiera una particular importancia, pues debido a él el lector se ve impulsado a constatar la identidad de ese "yo".

En su carácter libresco, la autoficción es capaz de atraer elementos de la realidad extratextual para transformarlos deliberadamente hasta el punto de disolverlos entre lo inventado. Pensemos no en informaciones biográficas o históricas, sino, por poner un ejemplo, en la inclinación de las autoficciones de acudir a la hibridación de géneros y a la utilización de registros discursivos no ficcionales (fotografía, entrevista, ensayo, notas periodística, memorias, etc.) que de manera simultánea realizan dos funciones: por un lado exhiben los artificios de la ficción y, por el otro, indican un afán de realismo que acuda al auxilio del personaje de autor. Con la identidad nominal ocurre algo similar, pues cuando no se utiliza el nombre completo de quien se presenta en la portada del libro como autor, el empleo de iniciales o alteraciones de este remiten a la dinámica de ocultación y exhibición mediante la cual se afirma y se niega al mismo tiemplo la identidad puesta en juego. Con todo, no son pocos los rastros de referencialidad en las autoficciones, lo que sucede es que en la novela todo acaba por

\footnotetext{
${ }^{2}$ A propósito de los rasgos que separan la autoficción de la autobiografía, Ana Casas señala que: "la convivencia de materiales de diverso origen (textos biográficos, históricos, ensayísticos, junto a textos ficcionales, fotografías, mapas, etc.) denuncia la idea de construcción, de artefacto, común a todos los textos (los pretendidamente autobiográficos y los abiertamente autoficcionales). El desorden cronológico, la estructura caótica, habitualmente digresiva de la autoficción, cuestionan, en fin, las nociones de sucesión y significación que en la autobiografía tienden a ofrecer una imagen de síntesis tanto de lo acontecido como del propio yo" (2012: 39). Para un análisis más detallado de los elementos que caracterizan la autoficción véase Toro (2017: 31-138).
} 
ficcionalizarse y, por lo tanto, el valor de la veracidad se minimiza. ${ }^{3}$ Queda, no obstante, la determinación realista que conserva nexos paradójicos con el afuera de la escritura, con una exterioridad que no puede ignorarse. Como explica Klaus Meyer-Minnemann:

Los seres, estados, procesos, acciones e ideas representados en una obra literaria de ficción se caracterizan por ser un producto de la invención (inventio), lo que equivale a decir que no pretenden (y no pueden pretender), en lo que representan, ser referenciables y/o susceptibles de someterse a la prueba de la verdad fáctica [...] Ello no quiere decir que algunos de estos seres, estados, procesos, acciones e ideas no se presten a establecer una referencia a seres, estados, procesos, acciones e ideas de la realidad extraliteraria, esto es, la realidad fáctica entendida como tal por el autor y/o receptores de una obra literaria de ficción, y que incluso el establecimiento de dicha referencia no forme parte de la intencionalidad del autor. (Meyer-Minnemann 2006: 49)

Es preciso dejar claro que al hablar de lo autobiográfico en términos referenciales no estamos al acecho de pruebas para verificar lo ocurrido; se trata, más bien, de sopesar las implicaciones de una vida traspuesta a la escritura, porque en estos dominios se pone en juego la resignificación de la experiencia mediante la creación de una trama enriquecida por los artificios de la invención.

Si bien el pacto de lectura ambiguo genera un espacio en el que es posible leer lo inventado como realmente acaecido y viceversa, al asumir la escritura autoficcional como una forma, o subgénero, de la novela se da por hecho que la imaginación del escritor prima sobre cualquier trazo autobiográfico. ${ }^{4}$ Sin embargo, cabe la posibilidad de una lectura en sentido contrario, pues las paradojas de la autoficción parecen ir descubriendo poco a poco un camino en retroceso de la narrativa de ficción, esto es, el vaciamiento del espacio fabulado para dar cabida a elementos factuales: acontecimientos, personas, lugares, etc., que si bien aparentan estar despojados de su valor referencial al entrar en el cuerpo de una novela, no hacen sino fingir una inventiva cuya riqueza reside precisamente en aquello que niega: la realidad empírica. Si esto es cierto, la vertiente literaria autoficcional comparte rasgos con las formas narrativas que Josefina Ludmer

\footnotetext{
3 Por ficcionalización se entiende la reproducción textual del referente en un plano ontológico donde la relación entre acciones y personajes se evalúa en términos de su verosimilitud y no según los valores de verdad que rigen a los enunciados no ficcionales, así como de acuerdo con la función pragmática del enunciado (comúnmente expresada en los paratextos). Como es sabido, dada la abundancia de las posturas sobre la ficcionalidad, no es posible delimitar una definición unívoca; sin embargo, puntualizaría, de la mano de Martínez Bonnati, que "[l]a regla fundamental de la institución novelística no es el aceptar una imagen ficticia del mundo, sino, previo a eso, el aceptar un hablar ficticio" (1992: 66).

${ }^{4}$ Si nos atenemos a la propuesta de Manuel Alberca, el pacto ambiguo es un pacto de lectura que está a medio camino entre el "pacto autobiográfico" (propuesto por Philippe Lejeune y fundado en la identidad nominal entre autor, narrador y personaje) y el pacto novelesco. Alberca ubica la autoficción dentro de la categoría de las "novelas del yo" y la define como "una novela o relato que se presenta como ficticio, cuyo narrador y protagonista tiene el mismo nombre que el autor" (2007:158).
} 
denomina -con un tono pesimista que predice el "fin de la autonomía de la literatura"- "literaturas posautónomas" o "escrituras diaspóricas" que

\begin{abstract}
no solo atraviesan la frontera de "la literatura" sino también la de "la ficción" [y quedan afuera-adentro]. Y esto ocurre porque reformulan la categoría de realidad: no se las puede leer como mero "realismo", en relaciones referenciales o verosimilizantes [...] toman la forma de escrituras de lo real: del testimonio, la autobiografía, el reportaje periodístico, la crónica, el diario íntimo, y hasta de la etnografía (muchas veces con algún "género literario" injertado en su interior: policial o ciencia ficción por ejemplo). No se sabe si los personajes son reales o no, si la historia ocurrió o no, si los textos son ensayos o novelas o biografías o grabaciones o diarios. (Ludmer 2007: s/p, énfasis mío) ${ }^{5}$
\end{abstract}

Así las cosas, resulta factible la posibilidad de que la referencialidad esté invadiendo la ficción en una vuelta de tuerca que contradice las afirmaciones sobre la naturaleza ficcional de la autobiografía o acerca de la construcción trópica del yo, como quería Paul de Man (1999: 113-118). Las incertidumbres de la autobiografía y la ambigüedad de la autoficción bien pueden leerse desde esa reformulación de la categoría de realidad a que alude Ludmer, pues al parecer también asumen como suyo un cierto contenido imaginado cuyo camuflaje es difícil distinguir: en las escrituras del yo se trata siempre de un sujeto más o menos inventado, pero siempre apoyado en la persona del autor. Después de todo, en la autoficción (si no es que en toda escritura del yo) "la ruptura de la verosimilitud realista se produce, no obstante, estrechando los lazos entre la obra literaria y el universo extratextual: la autoficción llama al referente para negarlo de inmediato; proyecta la imagen de un yo autobiográfico para proceder a su fractura, a su desdoblamiento o a su insustancialización (Casas 2012: 33-34).

Amén de lo autobiográfico, se puede describir la presencia del yo autoral en el texto en términos de lo que Pozuelo Yvancos denomina "figuración del yo", es decir, de un yo alejado de la entidad biográfica pero que continúa siendo "personal"; un yo manifestado en la forma de una voz reflexiva y, por lo tanto, discursivamente más cercana a la tesitura del ensayo, pues "permite construir al yo un lugar discursivo, que le pertenece y no le pertenece al autor, o le pertenece de una forma diferente a la referencial. Le pertenece como voz figurada, es un lugar donde fundamentalmente se despliega la solidaridad de un yo pensante y un yo narrante" (2012: 168). Si bien es cierto que la intervención textual del yo se puede leer de formas distintas a la autobiográfica -trátese del estilo o la ins-

\footnotetext{
${ }^{5}$ No es que las autoficciones hayan dejado de ser literatura, como afirma Ludmer a propósito de algunos libros leídos como novelas, pero cuyo valor estético se ha minimizado debido a la elección del lenguaje de las nuevas tecnologías de la comunicación y de contenidos prosaicos que simplifican o anulan los procedimientos autorreferenciales, intertextuales, poéticos, etc., característicos de la literatura de las décadas de 1960 y 1970. Véase también el planteamiento de Alejandro Quin sobre la noción de "posliteratura", que "nombra una paradoja de la cultura literaria contemporánea: la autonegación de la literatura mediante narrativas formalmente literarias cuyo lenguaje, sin embargo, ya no proviene de la tradición literaria sino de la expansión de los mass media y, en perspectiva amplia, de lo que Guy Debord acuñó como sociedad del espectáculo" (2014: 256).
} 
tauración de una visión de mundo, por mencionar algo-, la indecisión genérica característica de la autoficción toca directamente el problema de "lo real": se la niegue o se la acepte, la realidad del sujeto, con sus múltiples contradicciones, está en la base de su construcción. ${ }^{6}$ De modo que sopesar una verdad resulta obsoleto, pues bastaría simplemente con interpretar sus condiciones de posibilidad. El autor, en tanto centro de este movimiento oscilatorio entre el adentro y el afuera del texto, entre el ser y el no ser, invita a repensar los lugares en los que su figura, su imagen o su puesta en escena redefinen el trabajo escritural.

\section{EL AUTOR EN ESCENA}

El problema de la referencialidad es un problema de corporalidad, de someter la existencia de algo o el suceder efectivo de un acontecimiento a la comprobación factual. Por eso la instancia autorial resulta problemática y, al mismo tiempo, atractiva. Se podría decir que su naturaleza conceptual es la de una aporía: no se puede aprehender al ser de carne y hueso en la escritura; sin embargo, es solo gracias a esta que una vida se puede reconstruir, adquirir sentido. Si para Descartes pensar es existir, para el que relata su vida valdría la fórmula "Digo (narro), luego existo" o bien, si la transformamos mediante un giro relativo a la construcción de la identidad, el escritor declararía: "Soy lo que digo". La palabra es pues, como en el verbo encarnado del origen de la creación, dadora de vida. ¿Dónde debe, entonces, buscarse al autor? Al parecer, todo es cuestión del decir: el autor está en lo que dice de sí mismo y en lo que otros dicen de él. Su cuerpo, su materialidad, el sustento de su voz, se traduce o se transforma en un conjunto de discursos que en algún momento lo dotarán de una identidad. Sus actos, los públicos y los privados, parecen dirigirse hacia, girar en torno de y estar determinados por una actividad -la escritura- que, una vez hecha pública, genera una función -la del autor-y da forma a una identidad -su figura-. Y si el autor está ausente, es decir, si se presenta en la forma de la anonimia, la seudonimia o el apócrifo, subsiste aún la pregunta por el origen, un origen ligado siempre a la imagen del creador, alguien a quien poder atribuirle el acto enunciativo que origina al texto. Después de todo, resulta muy cierto que

La entidad racional que se conoce como autor es un compuesto solidario de presencia y ausencia. Cuando una de ellas se hace patente para el lector, este no dejará de advertir, como en un segundo plano, a la otra. El equilibrio constante pero inestable, de presencia y ausencia es lo que forma la autoría. Es su carácter fronterizo lo que define al autor. (López García 1993: 25)

\footnotetext{
${ }^{6}$ Ana Casas expone una lectura distinta de los textos autoficcionales: si bien admite el predominio de los trabajos que consideran la autoficción como "una modalidad de la escritura del yo erigida sobre un eje básicamente referencial -pese a las eventuales distorsiones ficcionales-", destaca una faceta de la autoficción poco considerada, pero que, en efecto, está en el otro lado del movimiento pendular entre la negación y la afirmación de la realidad empírica del autor: "la autoficción como expresión de un rechazo - o cuando menos de una actitud de perplejidad- ante la supuesta factualidad del autor" (2015: 175).
} 
Cada vez son más los estudios dedicados a reflexionar sobre el papel del autor y la autoría, hasta tal punto que se ha construido alrededor de la "autorialidad" toda una suerte de aproximaciones literarias, sociológicas, filosóficas, críticas, entre otras, que buscan reposicionar esta entidad que hace apenas unas cuantas décadas -desde, por lo menos, la década de 1970- entró en una apretada contienda contra las teorías estructuralistas y postestructuralistas, de la cual resultó, en apariencia, perdedora, aunque, como demuestran la cantidad de reflexiones al respecto, su victoria ha sido definitiva. $Y$ es que, en efecto, el autor siempre ha dado de qué hablar; por más que a toda costa se lo quiera silenciar, su voz, su figura, incierta muchas veces, está ahí siempre para dar cuenta de algo que la obra, por sí sola, no ha sabido decir del todo. En realidad, como apunta Ruth Amossy, el retorno del autor se ha dado solo en la crítica, porque el público nunca dejó de interesarse por la vida de escritores famosos ni la literatura por la encarnación del autor en sus personajes (2014: 68).

Dentro de la efervescencia teórica iniciada en Francia y marcada por el lugar, ya común, asignado a la "Muerte del autor" (1968), de Roland Barthes, es significativo el despliegue que han tenido los estudios sobre el autor durante los últimos diez o quince años en el ámbito hispánico y, más recientemente, en el hispanoamericano. ${ }^{7}$ Al parecer, esa supuesta desaparición del autor ha provocado sobresaltos por doquier, que han derivado en numerosos acercamientos para devolverle, si no la vida, sí el derecho de ser reconocido como parte fundamental del acontecimiento literario. Las palabras del propio Barthes han sido utilizadas para refutar su intento de borrar al creador de su creación. ${ }^{8}$ En Sade, Fourier, Loyola (1971), por ejemplo, Barthes parece admitir que un autor, con su corporalidad, sus poses, su presencia antes y después del libro, merece que su vida,

\footnotetext{
${ }^{7}$ Aunque con un ritmo más lento, el ámbito hispánico también ha visto prosperar el interés por el estudio del autor, como muestran, entre otros, las compilaciones de Ángeles Sirvent, Josefina Bueno y Silvia Caporale, Autor y texto: fragmentos de una presencia (1996), y más recientemente las de Juan M. Zapata, La invención del autor: nuevas aproximaciones al estudio sociológico y discursivo de la figura autorial (2014) y Aina Pérez Fontdevilla y Meri Torras Francés, Los papeles del autor/a. Marcos teóricos sobre la autoría literaria (2016), que se han encargado de traducir al español la producción más destacada sobre la autorialidad en distintos campos y en diferentes países; trabajo de Aina Pérez Fontdevilla y Meri Torras Francés es también el volumen ¿Qué es una autora? Encrucijadas teóricas entre género y autoría (2017); están además los estudios reunidos por Adriana de Teresa Ochoa en Horizontes teóricos y críticos en torno a la figura autoral contemporánea (2019); se cuentan, por lo demás, algunos números monográficos de revistas dedicados al autor: "Cuerpo y autori(ali)dad en la literatura, el arte y el texto ciematográfico", Estudios, n. ${ }^{\circ}$ 42 (2016); "Autoría y género", Mundo Nuevo. Revista de Estudios Latinoamericanos, vol. 7, n. 16 (2015); "La autoría a debate: textualizaciones del cuerpo-corpus", Tropelías. Revista de Teoría de la Literatura y Literatura Comparada, n. ${ }^{\circ} 24$ (2015).
}

${ }^{8}$ Aina Pérez Fontdevilla y Meri Torras, por ejemplo, afirman que "[n]isiquiera 'La muerte del autor' se libra del autor si lo comprendemos, con Foucault, como una función de la obra [...] ¿No es porque está marcado con la función autor 'Roland Barthes' que su texto puede devenir un lugar común de los estudios literarios, borrando provisionalmente al autor de la escena literaria?" Y más adelante: "'La muerte del autor' constituye una de las piezas del 'nombre de autor' 'Roland Barthes' en tanto contribuye a definir su contenido" (2016: 14-15. Véase, en este mismo volumen, el artículo de José-Luis Diaz, "Muertes y renacimiento del autor", para apreciar el recorrido por los varios momentos en la obra de Barthes dedicados a pensar sobre el autor. Díaz explica el paulatino movimiento de rechazo de Barthes hacia la figura autorial cuyo punto máximo es "La muerte del autor", después del cual parece generarse una especie de "renacimiento" o su aceptación). 
así sea como mera acumulación de biografemas, sea apreciada. En El placer del texto (1973) Barthes invoca al autor, le concede el lugar de un "objeto deseado", siempre presente en los encuentros del lector con el texto. ${ }^{9}$ La experiencia de la lectura es también un llamado al autor, es unas veces necesidad, otras, curiosidad o, como quiere Barthes, simplemente deseo. Será, sin embargo, en Roland Barthes por Roland Barthes (1975) donde el regreso del autor se completa, ya no como un guiño, sino como la entrada triunfal, si bien sigilosa, del propio Barthes convertido en la materia del libro, en un ser textual, un personaje que apuesta a no ser el autor pero que se le parece en todo, por más que desde el principio advierta: "Tout ici doit il consideré comme dit par un personnage de roman". Contraviniendo el principio de no contradicción, ese personaje juega a ser y no ser al mismo tiempo: es palabra y es cuerpo, es la escritura y el gesto, el movimiento de la mano sobre el papel, la sucesión de pensamientos venidos de un cuerpo.

Después de más de 40 años de la polémica iniciada por Barthes, seguimos deseando al autor, no nos conformarnos con darlo por hecho, ni mucho menos con ignorarlo buscándole sustitutos implícitos, astutos, o reemplazándolo con el lector. De ahí que la teoría se haya volcado a investigar las distintas formas de su presencia, a preguntarse de nueva cuenta, con Michel Foucault a la cabeza, "¿Qué es un autor?" o ¿qué tipo de relaciones se establecen entre el autor y la obra? y ¿cuál es papel de la autoría? De ahí también que en la literatura los escritores no dejen de darse a la tarea de hacerse las mismas preguntas, cuyas respuestas parciales se ofrecen en forma de ficción, mediante la voz de personajes portadores de identidades análogas a la del autor en cuestión.

Hoy en día asistimos a la "construcción del deseo de autor" (Louis 2013), que parte no solo del lector sino de la expresión abierta de lo deseado por el escritor, y coincide con los fenómenos mediáticos, responsables en buena medida de la creación de un espacio siempre expuesto donde toda presencia se convierte en objeto de un espectáculo. Así como, según Jérôme Meizoz, a lo largo de la historia de la literatura de Occidente los distintos debates han mantenido una tensión entre el interés por la obra o por el autor (2015: 31), la nuestra es una época en la que el autor impone su presencia por encima del valor de su obra: la era de la comunicación mediática encuentra en la figura del escritor un producto que puede venderse y, probablemente, generar más ganancias económicas que la obra misma. En palabras de Olivier Nora, "[h]oy en día consumimos la voz y la imagen del autor sin haber leído, en la mayoría de los casos, una sola línea de su obra: el efecto carismático propio de la escritura ya no reposa en la lectura, sino en el audio y en la visión" (cit. por Meizoz 2013: 256).

\footnotetext{
${ }^{9}$ Así lo expresa: "El texto es un objeto fetiche y ese fetiche me desea. El texto me elige mediante toda una disposición de pantallas invisibles de seleccionadas sutilezas: el vocabulario, las referencias, la legibilidad, etc.; y perdido en medio del texto (no por detrás como un deux ex-machina) está siempre, el otro, el autor". Y continúa: "Como institución el autor está muerto: su persona civil, pasional, biográfica, ha desaparecido; desposeída, ya no ejerce sobre su obra la formidable paternidad cuyo relato se encargaba de establecer y renovar tanto la historia literaria como la enseñanza y la opinión. Pero en el texto, de una cierta manera, yo deseo al autor: tengo necesidad de su figura (que no es ni su representación ni su proyección), tanto como él tiene necesidad de la mía (salvo si sólo 'murmura')" (1993: 47).
} 
Durante las últimas décadas el autor se ha estudiado a partir de, por lo menos, tres aspectos constitutivos: la persona, la instancia de enunciación textual y la "autoridad filológica [...] que posee un valor y establece un principio de clasificación" (Meizoz 2015: 34). "En su empleo más restringido", según Meizoz, el autor es a la vez estas tres instancias. Los intentos de aprehenderlo han conducido a una nueva multiplicación terminológica que sigue separando a la persona de su representación textual y de su construcción social, como función discursiva, quizás porque aún existe la necesidad de proteger a la persona de los efectos de su producción textual y de su imagen pública; porque la persona, o acaso su bios, estorba a la crítica y a la teoría; o simplemente porque conscientes de que el individuo nunca es uno, resulta necesario seguir aclarando que, textual, o literariamente, esa persona se transforma, quiéralo o no, en otro que es preciso considerar en sus relaciones complejas con eso que lo determina como autor: la obra y las instancias que intervienen en su producción. Aunque al parecer se han superado ciertas distinciones de la narratología (el autor implícito de Wayne Booth, por poner un ejemplo), se siguen estableciendo términos que dividen al autor en distintas instancias: para algunos se trata de distinguir a la persona del personaje; otros apuntan la separación entre el autor, el escritor y la persona o, como Dominique Maingueneau, entre la persona civil, el escritor y el escriptor (cit. por Meizoz 2014: 87). La nueva generación de estudios se está dedicando a investigar el funcionamiento de figuras autoriales en el seno de sus actuaciones discursivas y de los mecanismos de posicionamiento en un campo social determinado, al que se denomina, siguiendo los planteamientos de Pierre Bordieu, "campo literario" -entendido como el "espacio social delimitado por el valor simbólico y dotado de sus propias leyes de funcionamiento, modos de regulación y criterios de evaluación", en el que interactúan las instancias de producción, reproducción y legitimación (Zapata 2011: 44)-. Dentro del léxico adoptado para especificar los ámbitos o niveles entre los que se distribuye el estudio del autor se encuentran, entre otros, las nociones imagen, ethos y postura, por mencionar solo las más extendidas, cada una de las cuales intenta responder a las preguntas que plantean los distintos procesos de representación y construcción autoriales. ${ }^{10}$

\footnotetext{
${ }^{10} \mathrm{El}$ desarrollo de estos conceptos se ha generado principalmente en el seno del análisis del discurso (imagen, ethos) y de la sociología de la literatura (postura). Al considerar la literatura como fenómeno social, esta sociología estudia las obras en su relación con el productor (y el proceso de producción), la recepción y su momento histórico. Quizá la vertiente que más ha avanzado en los estudios del autor es la teoría del discurso; en relación con el texto literario, su propósito es analizarlo como una forma de comunicación, un uso particular de la lengua, en constante interacción con otros discursos y sus distintos contextos. Dominique Maingueneau, uno de los teóricos más prolíficos en este ámbito, indica que "[p]arler de 'discours littéraire', c'est en effet mobiliser un certain nombre d'idées-forces (le discours est une forme d'action, il est interactif, radicalement contextualisé, régi par des norms, dominé par un interdiscours, les textes son indisociables de genres, de discours, etc.) qui transforment les conditions mêmes dans lesquelles on peut étudier les productions verbales. II s'agit ainsi d'appréhender le texte comme le produit d'une activité s'exerçant dans le cadre d'institutions de parole qui légitiment un certain genre d'énonciation mais doivent aussi être continuellement relégitimées par l'énonciation que les encadrent" (2016b: 20).
} 
Grosso modo, el cometido de los planteamientos más recientes es apreciar la dinámica mediante la cual el autor se coloca en un lugar estratégico dentro del campo literario y, más concretamente, en el espacio textual. En otras palabras, la pregunta foucaultiana "¿Qué es un autor?" queda suspendida para dar pie, según Juan Zapata, al cuestionamiento sobre "¿Cómo se construye un autor?" (2011: 38) En este contexto, el surgimiento de una teoría de la función autorial (ubicada dentro de una "sociología del autor") pretende el estudio del autor dentro de su historicidad y en tanto "resultado de una operación compleja que construye un cierto ser de razón" (Zapata 2011: 38), lejos ya de las explicaciones textuales apoyadas en la vida o las intenciones del autor y, más lejos aún, de la inmanencia textual. Además de plantearse la pregunta por la relación entre el autor y su obra, la teoría de la función autorial busca descubrir la naturaleza de esa relación para la interpretación de un texto, pues reconoce que el productor influye de manera significativa en los modos de recepción, valoración y circulación de este.

En el nivel más general de la comunicación literaria, la figura de autor se crea a partir de tres instancias: la obra, el propio autor y la información procedente de terceros. Aunque cada una de ellas pueda crear una imagen distinta de las otras, nunca se dan de manera aislada, al contrario, hay siempre una relación de interdependencia entre ellas, pues tanto el interior del texto como su exterior (contexto) intervienen en la conformación de la entidad autorial. Sin embargo, en cuanto a su estudio concierne, la atención puede centrarse solo en uno de los tres factores. Así, por ejemplo, en el plano textual asistimos a la proyección de una imagen que el enunciador crea de sí mismo, si se admite que todo enunciado transmite señas de su enunciador. A esta representación verbal Dominique Maingueneau la denomina ethos. Su naturaleza es enteramente discursiva, es decir, se infiere de un texto particular y no corresponde necesariamente a la imagen del "locutor exterior" ni a las imágenes trasmitidas por otros de sus textos, aunque es susceptible de ser moldeada por los distintos "ethos prediscursivos" que el lector posee (Meizoz 2014: 88).

Ruth Amossy evoca el pasaje de Roland Barthes citado arriba para explicar la noción de ethos como una suerte de encarnación del "deseo de autor" que todo lector experimenta en el acto de la lectura, una figura con quien entablar un diálogo, entrar en comunión: "[a]l imaginar a aquel que se encuentra en el origen del texto, al atribuirle un rostro, un cuerpo, un carácter, unas opiniones, el lector intenta concretar un diálogo. Al hacerlo construye un personaje hipotético con el que le gustaría entrar en relación" (2014: 73). El ethos que el texto produce remite a un origen que, al conectarse con el nombre en la portada del libro, impone, según Amossy, la "sensación" de que alguien habla a través de él. Amossy destaca el paralelismo entre la noción de ethos y la de "autor implícito" de Booth, entidad que el lector deduce a partir de la selección particular de elementos narrativos y su combinación. Sin embargo, si se tiene en cuenta el carácter dialógico de esta construcción según un esquema comunicacional, este "autor implícito" (en tanto emisor de un enunciado ficcional) reclama la participación del lector; de ahí que, según Amossy, entre en juego la noción de "autor 
inducido", mediante la cual se plantea el problema de determinar si esta instancia autorial es "una construcción interpretativa del lector en lugar de uno de los polos de la comunicación" (2014: 74). La argumentación del discurso (análisis del discurso y retórica), apunta Amossy, reemplaza las nociones de "autor implícito" y "autor inducido" por la de ethos en lo que toca al análisis interno de los textos. Todo parece indicar que el ethos autorial es una composición que, sin ignorar la colaboración lectora, se presenta como un "efecto del texto" que reafirma "una dimensión del intercambio verbal" y "señala la manera mediante la cual el responsable de un texto, designado por un nombre propio, construye su autoridad y su credibilidad frente a los ojos del lector potencial" (Amossy 2014: 76).

Aunque el ethos resulta de las marcas textuales, su naturaleza es la de una cierta presencia que solo cobrará forma en la actualización de una "imagen de autor", en cuya elaboración participan tanto la obra como los metadiscursos. En este sentido, el ethos pasa a ser un elemento constitutivo de la imagen de autor. Si el ethos autorial es el resultado de la dinámica textual y su relación intrínseca con el productor, la imagen de autor, según los planteamientos de Dominique Maingueneau y Ruth Amossy, se construye como la "representación imaginaria de un escritor" (Amossy 2014: 77) en la que intervienen elementos textuales y extratextuales. Es decir, se trata de una forma que asume los rastros que el autor deja de sí en su creación -su ethos discursivo (o sus distintos ethos)-, las autorrepresentaciones desprendidas de los paratextos (prólogos, prefacios) y textos autobiográficos, así como la información transmitida por terceros en notas periodísticas, presentaciones de libro, anuncios, etc. No obstante, su heterogeneidad, la naturaleza imaginaria de esta figura excluye toda participación de la persona real: el autor deviene abstracción dotada de ciertos rasgos que la unen a una obra y la ubican en un lugar y en un momento histórico determinados.

En cambio, la noción de "postura" de Jérôme Meizoz implica, además de la conformación de una imagen, las conductas de la persona civil. Meizoz considera la postura como un concepto que va más allá de lo que Alain Viala describe como la manera de posicionarse en el campo literario. La instancia autorial, según Meizoz, adopta una suerte de máscara o "persona", en el sentido teatral, que acoge los efectos textuales y las conductas sociales del escritor (véase 2015: 9-24). En este sentido, la noción de "postura" incluye una dimensión retórica y otra sociológica, pues admite, además de la imagen textual que el enunciador construye de sí mismo (ethos) y las imágenes desprendidas de los distintos contextos discursivos, los comportamientos del escritor. Meizoz acude a la división de Mainguneau entre la persona civil, el escritor y el escriptor para establecer que el estudio de la postura debe tomar en cuenta "las conductas del escritor, el ethos del escriptor y los actos de la persona" (2014: 87). En efecto, Meizoz, como Maingueneau, reconoce estos tres aspectos de la instancia autorial como inseparables e interdependientes, ya que operan, como la cinta de Moebius, sobre una misma superficie. La naturaleza tripartita de la noción de autor es la que mejor da cuenta de las complejidades que genera su estudio y de su infructuosa separación de la entidad física que encarna la experiencia vital. En una analogía 
bíblica, el autor se compone, como el misterio de la Trinidad, de tres partes que son una y la misma cosa, según la siguiente figura:

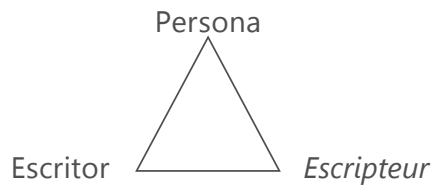

El hecho de que la persona, en tanto entidad biográfica, esté a la cabeza no indica una posición de superioridad sino simplemente de comienzo o, en todo caso, de asidero material, por así decirlo. Es preciso no perder de vista que estamos frente al fenómeno de la autoría moderna que, a diferencia de otras épocas donde el concepto de autor se muestra débil (piénsese en la Grecia Antigua o en la época Medieval), ${ }^{11}$ se apoya en la idea del ser humano como centro de toda actividad. En la cultura contemporánea la preeminencia de los procesos de subjetivación y su puesta a la luz pública conceden al autor un lugar privilegiado desde donde controlar y observar su propia hechura.

Aunque no especifica una división como tal en el estudio de la postura, Meizoz explica la forma en que esta se desprende tanto de los textos autobiográficos como de las ficciones y de la esfera pública. En la novela, el estudio de la postura es más complejo debido a las mediaciones que interponen los personajes, en quienes, según Meizoz, el autor se difracta. Sin embargo, la ficción participa en la construcción de una postura precisamente mediante indicadores como el estilo, el ritmo o el "tono", puesto que "toda tonalidad narrativa sigue una codificación retórica y produce una cierta imagen del enunciador novelesco" (Meizoz 2015: 21), imagen que Maingueneau identifica como el ethos. Públicamente, el escritor lleva a cabo un ejercicio de autocreación en la medida en que controla la disposición de su imagen ya no solo discursiva sino también física: cuando se expresa ante un público, la persona reúne "la función y el personaje" (Meizoz 2015: 23). Y es que "[u]na postura selecciona, en la biografía del autor o en su particular visión de mundo, los valores y los hechos que deben ser destacados en una suerte de 'fábula biográfica'."12

\footnotetext{
11 Aina Pérez Fontdevilla y Meri Torras Francés (2016) observan la existencia alternada entre una autoría fuerte y otra débil a lo largo de la historia de la literatura en Occidente. Es fuerte cuando el autor adquiere una mayor presencia en el campo literario al generar interés por su persona o participar de manera más activa en los procesos que acompañan la creación y difusión de su obra, como ocurrió durante el Romanticismo. Por el contrario, se identifica como débil cuando el centro de atención está en la obra mientras que el creador queda al margen, como sucedió en la Edad Media y en los años que vieron tomar fuerza a la "muerte del autor".

12 De acuerdo con Meizoz, toda postura también toma de la tradición o del imaginario social construcciones estereotípicas que han perpetuado ciertas poses o actitudes creadas o adoptadas por otros escritores a lo largo de la historia. Ponerse el traje de "escritor maldito", por poner un ejemplo, indica la apropiación de unos valores, creencias e ideas que de algún modo encarnarán también en la obra (2015:15-20). Estos comportamientos estereotípicos se incluyen en la noción de "escenografías autoriales" propuesta por José-Luis Diaz (2016).
} 
La perspectiva de Meizoz indica la posibilidad de admitir a la "persona real" a condición de que se no se pierdan los vínculos con sus "comportamientos literarios", es decir, con las representaciones textuales y sociales enmarcadas en el acto de enunciación de la literatura, pues este no surge ni se desenvuelve de manera autónoma y aislada, sino que es el resultado de la interacción entre distintas fuerzas. Si en todo acto de comunicación intervienen un emisor y un receptor, no se puede ignorar la participación que ambos cumplen en el proceso. ${ }^{13} \mathrm{Al}$ admitir que la imagen del autor se apoya en la persona civil, Meizoz se aventura a pisar sobre el terreno flojo de la referencia, de donde proviene la voz que luego se encargará de crear y asumir una imagen y con ella una postura, esa "identidad literaria" que hace al autor. Porque el escritor de nuestros días es una figura pública cuyos actos moldean la recepción de su obra y de su figura, concederle un espacio en el análisis literario entraña el reconocimiento de su postura, pero también la aceptación de que, más allá de los riesgos implicados en su estudio, y a pesar de ellos, el autor es un ser de carne y texto.

Acaso porque, como asegura Meizoz, el enunciador del texto y la persona biográfica son dos niveles de una misma instancia autorial, el lugar donde la postura se exhibe de manera más directa, pero también más engañosa, se encuentra en la escritura autobiográfica. Por regla general, se puede decir que, en este tipo de escritura, la imagen que el autor construye de sí mismo se apoya en su "persona civil o biográfica"; estos textos, asegura Meizoz,

despliegan una postura, una construcción que el autor hace de sí mismo y que debe ser analizada con relación al estado del campo artístico en cuestión. No se trata del sujeto civil o biográfico, o por lo menos no únicamente de este, sino de un sujeto construido que el autor lega a los lectores en y a través del trabajo de la obra. (Meizoz 2015: 20)

Aquí, la autofiguración impone por sí misma la construcción de una imagen que puede o no coincidir con las autorrepresentaciones del autor en otros contextos, con las imágenes producidas por terceros o con los ethos desprendidos de otras de sus producciones, pero que, en cambio, se adhiere a una postura determinada. Por eso, si cualquier texto plantea el problema de su origen y despierta el "deseo de autor", en los géneros autobiográficos el problema se multiplica, el deseo se convierte en una exigencia: el autor reclama ser visto, interrogado,

\footnotetext{
13 En la percepción del autor en su obra la participación del lector es fundamental: es requisito que el lector posea conocimientos previos con los cuales apreciar el contenido en su justa dimensión. Sin ese acervo, la interpretación quedaría incompleta. Por ello, no se podría leer una autoficción como tal si el lector no se percata de la identidad, más allá del nombre, entre autor, narrador y personaje. Sin embargo, aunque la participación del lector es definitiva en la actualización de una obra, su lugar no es el mismo que el del autor, no se encuentran al mismo nivel creativo: el autor crea, el lector interpreta. El lector, a diferencia del autor, es una entidad anónima, impersonal -a menos que se trate del lector-crítico, quien al hacer pública su lectura y su nombre, asume una responsabilidad y, por lo tanto, se convierte él mismo en autor- cuyos valores y creencias moldean, solo para él, el contenido del libro. El autor, en cambio, tiene una influencia constante en su texto, mucho más si se trata de alguien que desde otros foros públicos modifica continuamente las opiniones del lector. Este, en efecto, puede ser un co-creador, en la medida en que imagina, reinventa, para sí mismo, el libro.
} 
analizado en sus autorrepresentaciones y en la interacción de estas con otros discursos, suyos o ajenos. Genera así una "escena de enunciación" a la doble potencia; el autor se enfrenta a las dificultades de hacer coincidir, o por lo menos interactuar, las distintas imágenes que se encuentran en circulación para dar lugar a una figura coherente. De ahí que la autobiografía se proponga hacer de esta figura un mediador entre el ethos (o los distintos ethos) emanado de su obra y las representaciones producidas en el contexto. De ahí también que procure la emanación de una postura revestida con las marcas particulares de una poética: el autor se asume como determinada persona convertida en determinado escritor, con ciertas tendencias, modelos, preferencias estilísticas y temáticas, vocabulario, recursos, en fin todo aquello que lo particulariza.

Por su parte, la autoficción problematiza las relaciones entre la persona civil y sus manifestaciones autoriales en el campo literario, ya que incorpora a la imagen rasgos que conciernen a un personaje de novela, pero que, con frecuencia, terminan por ocupar el mismo estatuto de realidad que los contenidos biográficos. La postura en esta zona paradójica no se apoya en la correspondencia entre ethos e imagen, como en la autobiografía, porque la misma determinación identitaria entre las instancias que intervienen en la narración autobiográfica (según la formula "autor = narrador = personaje" propuesta por Philipe Lejeune) efectúa un movimiento simultáneo de afirmación y negación de la figura autorial con respecto a las informaciones previas (ethos prediscursivo) que posee el receptor. De este modo, el régimen ficcional a que se somete la autoficción tiene la virtud de hacer que la autofiguración del autor desplegada en su dominios se imponga como correlato de la postura que, bajo el mismo nombre, porta en otros contextos y negocia con las atribuciones de terceros.

Lo hasta aquí expuesto indica que el nuevo estudio de la instancia autorial apunta hacia dos direcciones complementarias: una que va de la obra y el contexto hacia la determinación del autor, y otra que, apoyándose en la persona civil y las distintas realizaciones de lo que está en la base de su identidad en tanto escritor (experiencias, recuerdos, afectos, creencias, ideologías) regresa al texto para complejizar no únicamente su autocreación sino la estructura narrativa que la soporta. Desde esta perspectiva, una de las consecuencias más ricas de la construcción de una figura textual de autor es que su paso por la ficción moviliza una serie de procedimientos narrativos (metaficcionales, intertextuales, vocales y de perspectiva, simbólicos, etc.) mediante los cuales se destaca una parte de las múltiples relaciones escritor-escritura, donde ya no es posible establecer límites entre un afuera y un adentro del texto, porque el adentro deviene afuera y viceversa. El estudio del autor, en este sentido, sirve a la literatura para conectar al texto con el contexto (en sus variadas facetas), pero también para averiguar las implicaciones -estéticas y éticas- de su empeño en introducirse e invadir, en convertirse en centro, de un espacio producto de su invención.

Trátese de la persona civil, del escritor, del escriptor o de un ethos, de percibir una imagen o apreciar una postura, la encrucijada que plantea la autorialidad es hasta cierto punto la misma de la escritura autobiográfica: ¿hasta dónde es posible separar al autor de la persona del escritor?, ¿en qué momento el escri- 
tor deja de ser él (el ser que piensa, siente, vive) y se convierte en la abstracción bajo cuyo nombre los otros reúnen, leen, interpretan un conjunto heterogéneo de realizaciones discursivas? El estudio de la relación del autor con su obra es de por sí complejo; estudiarlo cuando se empeña en transformarse en entidad textual o en trasladar su identidad a un personaje de ficción encierra las irresoluciones de la paradoja, porque, a decir de Sabine Lang, en tanto recurso de la novela moderna, la paradoja "señala un momento de crisis (cognitiva) en el que todo está puesto en tela de juicio, en el que nada aparece dado unívocamente, en que cada Uno y cada Otro, tanto en relación a sí mismos como entre sí, 'es y no es todo al mismo tiempo y en todas las maneras posibles'" (2006: 22). Lo que nos queda de la imposibilidad de hacer manejable al autor en términos de referencia es aprehenderlo justo en la zona incierta que reclama su pertenencia simultánea a dos reinos, en el umbral del texto, en ese lugar paradójico donde el que dice "yo" es el autor precisamente cuando deja de serlo.

\section{OBRAS CITADAS}

Alberca, Manuel (2007): El pacto ambiguo. De la novela autobiográfica a la autoficción. Madrid, Biblioteca Nueva.

Bajtín, Mijaíl (1982): "Autor y personaje en la actividad estética". En: Estética de la tradición verbal. Trad. Tatiana Bubnova. México, Siglo XXI.

Amossy, Ruth (2014): "La doble naturaleza de la imagen de autor". En: Juan Zapata (comp.): La invención del autor: nuevas aproximaciones al estudio sociológico y discursivo de la figura autorial. Medellín, Universidad de Antioquia, pp. 67-84.

Barthes, Roland (1993): El placer del texto. Lección inaugural. Trad. Nicolás Rosa (El placer del texto) y Oscar Tebán (Lección inaugural). México, Siglo XXI.

(1975): Roland Barthes par Roland Barthes. París, Seuil.

Bennett, Andrew (2005): The Author. Londres / Nueva York, Routledge.

Casas, Ana (2015): "Desmontando al autor: ironía, parodia y sátira en la narrativa y el cine autoficcionales", Tropelías, n. 24, pp. 174-190.

— (2012): "El simulacro del yo: la autoficción en la narrativa actual". En Ana Casas (comp.): La autoficción. Reflexiones teóricas. Madrid, Arco Libros, pp. 9-42.

De Man, Paul (1991): "La autobiografía como desfiguración", Suplementos Anthropos, n. 29, pp. 113-118.

Diaz, José-Luis (2016): "Muertes y renacimiento del autor". En: Aina Pérez Fontdevilla y Meri Torras Francés (eds.): Los papeles del autor/a. Marcos teóricos sobre la autoría literaria. Madrid, Arco Libros, pp. 55-77.

Diccionario de la Real Academia Española (2014). 23ª ed. Madrid.

Lang, Sabine (2006): "Prolegomenos para una teoría de la narración paradójica". En Nina Grabe, Sabine Lang y Klaus Meyer-Minnemann (eds.): La narración paradójica. "Normas narrativas" y el principio de la "transgresión". Madrid, Iberoamericana-Vervuert, pp. 21-47.

Lejeune, Philippe (1994): El pacto autobiográfico y otros estudios. Trad. Ana Torrent. Madrid, Megazul-Endymion. 
López García, Dámaso (1993): Ensayo sobre el autor. Barcelona, Júcar.

Loureiro, A. G. (1991): "Problemas teóricos de la autobiografía", Suplementos Anthropos, $n^{\circ} .29$, pp. 2-9.

Louis, Annick (2013): "Monumento Borges o ¿Qué es hoy un autor?", Inti: Revista de Literatura Hispánica, nº.77-78, pp. 237-248. En línea: <http://digitalcommons.providence. edu/cgi/viewcontent.cgi?article=2715\&context=inti> [última visita: 15.2.2018].

Ludmer, Josefina (2017): "Literaturas postautónomas", Ciberletras, n. 17. En línea: <http:// www.lehman.cuny.edu/ciberletras/v17/ludmer.htm> [última visita: 30.7.2018].

Maingueneau, Dominique (2016a): "El ethos: un articulador". En Aina Pérez Fontdevilla y Meri Torras Francés (eds.): Los papeles del autor/a. Marcos teóricos sobre la autoría literaria. Madrid: Arco Libros, pp. 131-154.

- (2016b): Trouver sa Place dans le Champ Littéraire. Paratopie et Creation. París, Academia/L'Harmattan.

Martínez Bonati, Félix (1992): La ficción narrativa (su lógica y ontología). Murcia, Universidad de Murcia.

Meizoz, Jérôme (2013): "'Escribir, es entrar en escena': la literatura en persona", Estudios: Revista de Investigaciones Literarias y Culturales, vol. 42, pp. 253-269. En línea: <http://orbi.ulg.ac.be/handle/2268/202915> [última visita: 23.5.2018].

_ (2014): "Aquello que le hacemos decir al silencio: postura, ethos, imagen de autor". En Juan Zapata (comp.): La invención del autor: nuevas aproximaciones al estudio sociológico y discursivo de la figura autorial. Medellín, Universidad de Antioquía, pp. 85-96.

- (2015): Posturas literarias. Puestas en escena modernas del autor. Trad. y pról. Juan Zapata. Bogotá, Universidad de Los Andes, Facultad de Artes y Humanidades, Departamento de Humanidades y Literatura / Ediciones Uniandes.

Meyer-Minnemann, Klaus (2006): "Narración paradójica y ficción". En Nina Grabe, Sabine Lang y Klaus Meyer-Minnemann (eds.): La narración paradójica. "Normas narrativas" y el principio de la "transgresión". Madrid/Frankfurt, Iberoamericana-Vervuert, pp. 49-71.

Pérez Fontdevilla, Aina; y Torras Francés, Meri (2016): "Hacia una biografía del concepto de autor". En Aina Pérez Fontdevilla y Meri Torras Francés (eds.): Los papeles del autor/a. Marcos teóricos sobre la autoría literaria. Madrid, Arco Libros, pp. 11-51.

_ (eds.) (2016): Los papeles del autor/a. Marcos teóricos sobre la autoría literaria. Madrid, Arco Libros.

Quin, Alejandro (2014): "Median Reyes: impostura, sujeción y riesgo". En Juan Zapata (comp.): La invención del autor. Nuevas aproximaciones al estudio sociológico y discursivo de la figura autorial. Medellín, Universidad de Antioquia, pp. 256-268.

Woodmansee, Martha (1994): "On the Author Effect: Recovering Collectivity". En Martha Woodmansee y Peter Jaszi (eds.): The Construction of Authorship. Textual Appropiation in Law and Literature. Durham/Londres, Duke University Press.

Yvancos Pozuelo, José María (2012): "'Figuración del yo' frente a autoficción". En Ana Casas (comp.): La autoficción. Reflexiones teóricas. Madrid, Arco Libros, pp. 151-173.

— (1993): "La frontera autobiográfica". En: Poética de la ficción. Madrid, Síntesis, pp. 179226. 
Zapata, Juan (comp.) (2014): La invención del autor. Nuevas aproximaciones al estudio sociológico y discursivo de la figura autorial. Medellín, Universidad de Antioquia.

(2011): "Muerte y resurrección del autor. Nuevas aproximaciones al estudio sociológico del autor", Lingüística y Literatura, nº. 60, pp. 35-58. 